\title{
OPEN Occupational exposure and radiobiological risk from thyroid radioiodine therapy in Saudi Arabia
}

\author{
H. I. Al-Mohammed ${ }^{1}$, A. Sulieman ${ }^{2}$, Fareed H. Mayhoub ${ }^{3}$, Hassan Salah ${ }^{4,5}$, \\ Celestino Lagarde ${ }^{3}$, M. Alkhorayef ${ }^{6,7}$, Ali Aldhebaib ${ }^{8}$, C. Kappas ${ }^{9}$ \& D. A. Bradley,10
}

Worldwide, thyroid cancer accounts for some $10 \%$ of total cancer incidence, most markedly for females. Thyroid cancer radiotherapy, typically using ${ }^{131} \mathrm{I}\left(\mathrm{T}_{1 / 2} 8.02\right.$ days; $\beta^{-}$max energy $606 \mathrm{keV}$, branching ratio $89.9 \%$ ), is widely adopted as an adjunct to surgery or to treat inoperable cancer and hyperthyroidism. With staff potentially receiving significant doses during source preparation and administration, radiation protection and safety assessment are required in ensuring practice complies with international guidelines. The present study, concerning a total of 206 patient radioiodine therapies carried out at King Faisal Specialist Hospital and Research Center over a 6-month period, seeks to evaluate patient and occupational exposures during hospitalization, measuring ambient doses and estimating radiation risk. Using calibrated survey meters, patient exposure dose-rate estimates were obtained at a distance of $30-, 100$ - and $300 \mathrm{~cm}$ from the neck region of each patient. Occupational and ambient doses were measured using calibrated thermoluminescent dosimeters. The mean and range of administered activity (AA, in $\mathrm{MBq}$ ) for the thyroid cancer and hyperthyroidism treatment groups were $4244 \pm 2021$ (1669-8066), 1507.9 $\$ 324.1$ (977.9-1836.9), respectively. The mean annual occupational doses were $1.2 \mathrm{mSv}$, that for ambient doses outside of the isolation room corridors were found to be $0.2 \mathrm{mSv}$, while ambient doses at the nursing station were below the lower limit of detection. Exposures to staff from patients being treated for thyroid cancer were less compared to hyperthyroidism patients. With a well-defined protocol, also complying with international safety requirements, occupational exposures were found to be relatively high, greater than most reported in previous studies.

In Saudi Arabia, the incidence of thyroid cancer (TC) accounts for $11 \%$ of the total cancer incidence, making it the 2 nd most common cancer in the country. The incidence of thyroid cancer is greater in females, $77.7 \%$, compared to $22.3 \%$ in males $^{1}$ for males alone it is the 8 th most common cancer. This incidence is significantly greater than that in the USA, wherein thyroid cancer represents only $2.9 \%$ of all malignancies and $4.6 \%$ of all female malignancies ${ }^{2,3}$. The median age and range at diagnosis were $39.0(4.0-95.0)$ and $44.0(8.0-95.0)$ years, for females and males respectively ${ }^{1}$. The incidence of thyroid cancer continues to increase in Saudi Arabia, with

\footnotetext{
${ }^{1}$ Department of Radiological Sciences, College of Health and Rehabilitation Sciences, Princess Nourah Bint Abdulrahman University, P.O. Box 84428, Riyadh 11671, Saudi Arabia. ${ }^{2}$ Radiology and Medical Imaging Department, College of Applied Medical Sciences, Prince Sattam Bin Abdulaziz University, P.O. Box 422, Alkharj 11942, Saudi Arabia. ${ }^{3}$ King Faisal Specialist Hospital \& Research Centre, Riyadh, Saudi Arabia. ${ }^{4}$ Nuclear Medicine Department, INAYA Medical Collage, Riyadh 13541, Saudi Arabia. ${ }^{5}$ College of Medical Radiologic Science, Sudan University of Science and Technology, P.O. Box 1908, Khartoum 11111, Sudan. ${ }^{6}$ Department of Radiological Sciences, College of Applied Medical Sciences, King Saud University, P.O. Box 10219, Riyadh 11433, Saudi Arabia. ${ }^{7}$ Department of Physics, Centre for Nuclear and Radiation Physics, University of Surrey, Guildford GU2 7XH, Surrey, UK. ${ }^{8}$ Radiological Sciences Program, College of Applied Medical Sciences (COMAS), King Saud Bin Abdulaziz University for Health Sciences (KSAU-US), King Abdul Aziz Medical City (KAMC), King Abdullah International Medical Research Centre (KAIMRC), National Guard Health Affairs (NGHA), Riyadh, Kingdom of Saudi Arabia. ${ }^{9}$ Department of Medical Physics, Medical School, University of Thessaly, 41110 Larissa, Greece. ${ }^{10}$ Centre for Applied Physics and Radiation Technologies, School of Engineering and Technology, Sunway University, Jalan Universiti, 47500, Bandar Sunway, Selangor, Malaysia. ${ }^{\varpi}$ email: Abdelmoneim_a@yahoo.com
} 
a $24 \%$ increase in males and a $63 \%$ increase among females over the ten-year period up to $2018^{1}$. For treatment, it has been estimated that about $60 \%$ received combined modality treatment consisting of surgery, radiation, and hormonal therapy. Thyroid disease treated with radioiodine $\left({ }^{131} \mathrm{I}\right)$ includes cancer and non-cancerous diseases such as hyperthyroidism (thyrotoxicosis). Both are treated with radioiodine therapy I-131 to detect any area of residual thyroid tissue or tumour. Thyroidectomy is regularly performed on the malignant tumour ${ }^{4}$. Other promising technology was used, such as thermal ablative (TA), as alternative treatment options for thyroid diseases and has successfully succeeded in cancer treatment. The volume reduction rate (VRR) of the tumour exceeds $99 \%$. TA procedures are known to be effective also in combination with radioiodine-131 treatment ${ }^{5-7}$. TA such as microwave ablation (MWA) use hyperthermia effects to destroy tumours through protein denaturation. The procedure is safe and effective in treating thyroid cancer. It provides innovative alternative therapy with minimal postoperative distress, shorter time of operation, and hospitalization stay, which can considerably increase the patients' lives ${ }^{8}$. However, some complications were reported during MWA including, hoarseness, skin burning sensation, and haemorrhage ${ }^{9,10}$. Laser ablation (LA, $\lambda=1064 \mathrm{~nm}$ and power $=3-4$ Watts) under ultrasound guidance is used for thyroid cancer treatment and accomplished high therapeutic outcomes with less cost and complications than surgical operation ${ }^{10}$. The main drawback of LA is the high temperature $\left(\approx 110^{\circ} \mathrm{C}\right)$, which could cause tissue burning, which may result in wound healing delay ${ }^{11}$. Radiofrequency ablation (RFA) has a comparable outcome with complications less than $4.5 \%{ }^{12}$, with effective and safe treatment when surgical intervention cannot be executed ${ }^{8,13,14}$. High-Intensity Focused Ultrasound (HIFU) is used to eradicates tumours cells by thermal coagulation $\left(\approx 60^{\circ} \mathrm{C}\right)$ while sparing the superficial tissues ${ }^{15}$, with limited complications ${ }^{16}$. TA main complications are thermal damage, which could be relieved in a short period. The overall safety of the TA techniques is primary tumour location dependant. Operator experience was reported to be crucial in procedural complications ${ }^{8}$. However, in this study, all thyroid cancer patients underwent surgical operation (thyroidectomy) followed by radioiodine therapy as standard protocol ${ }^{10,17}$. Radioiodine provides sufficient curative outcome, including patients with metastatic thyroid cancer ${ }^{18}$.

Concerning thyroid disorders and the associated theranostic clinical applications, radioactive iodine-131 $\left(\mathrm{Z}=53, \mathrm{~T}_{1 / 2}=8.02\right.$ days $)$ has now been used as an unsealed source for a period of in excess of seven decades, offering $90 \%$ beta emission $(606 \mathrm{keV}$, range in tissue $=0.8 \mathrm{~mm})$ and $10 \%$ gamma emission $(364 \mathrm{keV})^{19} .{ }^{131} \mathrm{I}$ cancer ablation (for total thyroidectomy), using activities ranging between 1110 to $7400 \mathrm{MBq}$ (30-200 mCi) provides an excellent treatment option, an exact and targeted therapy with minimal side effects, allowing preservation of healthy tissues and cells beyond the tumour region, with monitoring of the disease using thyroglobulin serum levels ${ }^{20,21}$. In addition, thyroid remnant ablation by radioactive iodine (RAI) during thyroid hormone withdrawal(THW) has a high rate of complete ablation $(75-90 \%)$ when high activity $(3.5-3.7 \mathrm{GBq})$ is used ${ }^{20}$.

Exposure to ionizing radiation from different sources (fallout, the Chernobyl accident, medical exposures, etc.) have lead to cases of cancer, high energies and penetration giving rise to DNA damage ${ }^{22}$. Medical personnel (medical physicists, technologists, physicians, and nursing staff) interact with RAI-treated patients, after administration of radioiodine, including the entire period of hospitalization; hence they are exposed to ionizing radiation emitted by the patients. Radiation exposure depends on the time, distance, shielding, and workload; thus, staff exposure is variable. Recent studies have shown medical physicists, technologists, and nurses receiving annual doses of 604-, 680-, and $1000 \mu \mathrm{Sv}$ respectively ${ }^{23-25}$. Abu-Khaled et $\mathrm{al}^{26}$ reported respective annual shallow and deep dose values at various locations, including at the patient bed (226- and $175 \mathrm{mGy}$ ), bathroom (94 and $72 \mathrm{mGy}$ ) and visitor reception (12 and $10 \mathrm{mGy}$ ). Reported effects include that ionizing radiation occupational exposure induces DNA damage in the leukocytes of nuclear medicine employees ${ }^{27}$.

Unsealed radiopharmaceuticals such as ${ }^{131} \mathrm{I}$ are frequently used in the nuclear medicine department for therapeutic purposes, potentially giving rise to significant occupational doses, up to $7.7 \mathrm{mSv}$ per year in the recorded study of Bitar et $\mathrm{al}^{24}$. Thus, it is essential to ensure that staff receive minimal occupational dose from external and internal incorporated radioiodine, the latter due to inhalation of radioactive iodine due to its volatile nature (airborne iodine as an aerosol, $\mathrm{CH}_{3} \mathrm{I}$ and iodine vapour $\left(\mathrm{I}_{2}\right)$ ) $^{28-30}$. Miszczyk et al ${ }^{31}$ have reported staff radioiodine incorporation at a nuclear medicine department of up to $217 \pm 56 \mathrm{~Bq}$. Krajewska \& Pachocki ${ }^{32}$ measured the mean and range of radioiodine activity $(\mathrm{Bq})$ in the thyroid of the personnel at nuclear medicine staff were 83 (70-250), 280 (70-4000), and 275 (70-1000) for technical personnel, nuclear medicine personnel, and hospital service personnel, respectively. Therefore, the measurement of occupational radiation exposure and assessment of the associated biological risk is crucial in seeking to ensure staff are working in a safe environment. The objectives of this study has been to evaluate patient and occupational exposures arising from therapeutic radioiodine procedures, also measuring ambient doses and estimating the radiation risk.

\section{Materials and methods}

Radiation dose measurements. Occupational exposure was measured for seven personnel involved in the ${ }^{131} \mathrm{I}$ radioiodine treatment of 182 patients receiving thyroid cancer therapy (138 (75.8\%) female and $44(24.2 \%)$ male) and 24 patients receiving treatment for hyperthyroidism (3 (12.5\%) males and 21(87.5\%) females), all within a one year period at King Faisal Specialist Hospital and Research Center (KFSHRC) (Tables 1 and 2). In the Kingdom of Saudi Arabia (KSA) KFSH\&RC is one of the leading referral centers for thyroid cancer treatments with radioiodine. The Ethics and Research Committee at KFSH\&RC center approved the research (RAC: 2201283), and written inform consent was obtained from each patient's prior data collection. Patient data include age, weight, and body mass index $\left(\mathrm{BMI}, \mathrm{kg} / \mathrm{m}^{2}\right)$; administered activity and exposure geometry were also detailed.

Patient demographics and radioiodine administration. At this center radioiodine therapy is via oral administration of capsules. Each radioiodine capsule also contains sodium thiosulphate $\left(\mathrm{Na}_{2} \mathrm{O}_{3} \mathrm{~S}_{2}\right)$ and diso- 


\begin{tabular}{|c|c|c|c|c|c|}
\hline Gender & No. patient & Age (y) & Height (m) & Weight (kg) & BMI $\left(\mathrm{kg} / \mathrm{m}^{2}\right)$ \\
\hline Male & 44 & $\begin{array}{l}(44.3 \pm 14.9) \\
(21-77)\end{array}$ & \begin{tabular}{|l|}
$(1.8 \pm 0.1)$ \\
$(1.56-1.89)$
\end{tabular} & $\begin{array}{l}(94.1 \pm 16.3) \\
(67.9-129.0)\end{array}$ & $\begin{array}{l}(30.7 \pm 4.7) \\
(22.0-40.7)\end{array}$ \\
\hline Female & 138 & $\begin{array}{l}(42.7 \pm 13.7) \\
(16-81)\end{array}$ & $\begin{array}{l}(1.7 \pm 0.1) \\
(1.3-1.7)\end{array}$ & $\begin{array}{l}(72.3 \pm 14.9) \\
(33.7-112.6)\end{array}$ & $\begin{array}{l}(29.5 \pm 5.9) \\
(15.4-43.4)\end{array}$ \\
\hline Total & 182 & $\begin{array}{l}(43.5 \pm 14.3) \\
(16-81)\end{array}$ & $\begin{array}{l}(1.75 \pm 0.1) \\
(1.3-1.89)\end{array}$ & \begin{tabular}{|l|}
$(83.2 \pm 15.6)$ \\
$(33.7-129)$
\end{tabular} & $\begin{array}{l}(30.1 \pm 5.3) \\
(15.4-43.4)\end{array}$ \\
\hline
\end{tabular}

Table 1. Mean, $\pm S d$ and range of patient demographic data in thyroid cancer by using Iodine-131.

\begin{tabular}{|l|l|l|l|l|l|}
\hline Gender & No. patient & Age & Height $(\mathbf{m})$ & Weight $(\mathbf{k g})$ & BMI $\left(\mathbf{k g} / \mathbf{m}^{2}\right)$ \\
\hline Male & 3 & $\begin{array}{l}(48.0 \pm 25.16) \\
(19-64)\end{array}$ & $\begin{array}{l}(1.72 \pm 0.02) \\
(1.7-1.73)\end{array}$ & $\begin{array}{l}(77.95 \pm 0.1) \\
(77.9-78.0)\end{array}$ & $\begin{array}{l}(26.51 \pm 0.63) \\
(26.06-26.96)\end{array}$ \\
\hline Female & 21 & $\begin{array}{l}(35.24 \pm 10.2) \\
(20-61)\end{array}$ & $\begin{array}{l}(1.58 \pm 0.05) \\
(1.5-1.67)\end{array}$ & $\begin{array}{l}(70.1 \pm 16.48) \\
(55.1-97.0)\end{array}$ & $\begin{array}{l}(27.97 \pm 6.5) \\
(22.1-39.4)\end{array}$ \\
\hline Total & 24 & $\begin{array}{l}(41.62 \pm 17.68) \\
(19.0-76)\end{array}$ & $\begin{array}{l}(1.65 \pm 0.04) \\
(1.5-1.73)\end{array}$ & $\begin{array}{l}(74.03 \pm 8.3) \\
(55.1-97.0)\end{array}$ & $\begin{array}{l}(27.2 \pm 3.57) \\
(22.1-39.4)\end{array}$ \\
\hline
\end{tabular}

Table 2. Mean, \pm Sd and range of patient demographic data in hyperthyroidism by using Iodine-131.
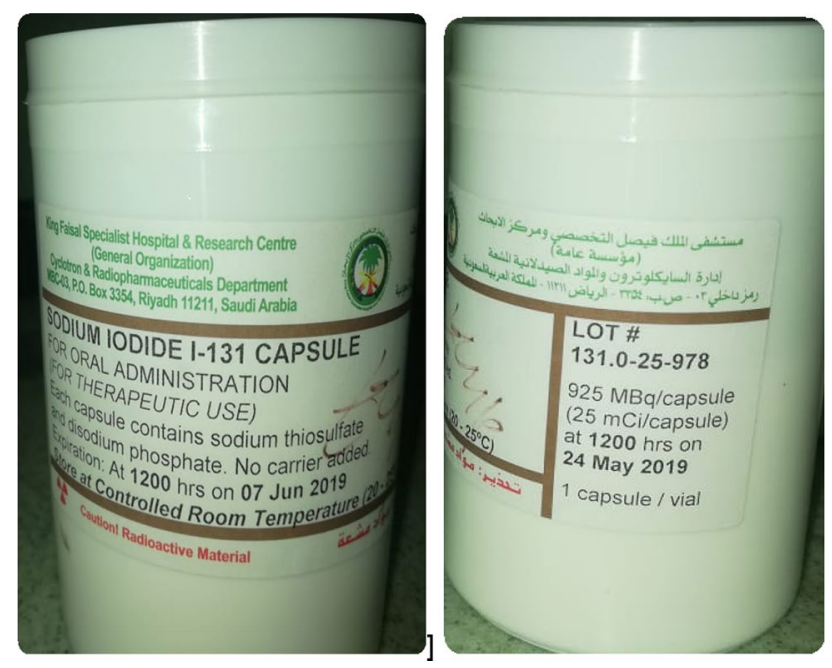

Figures 1. (A,B) Radioactive iodine.

dium sulfate $\left(\mathrm{Na}_{2} \mathrm{O}_{4} \mathrm{~S}\right)$ (Fig. 1). ${ }^{131} \mathrm{I}$ was administered in the hospital at the patient bed of each patient. In this, in respect of potential spills etc., the patient was asked to sit at a table covered with adsorbent pads; the floor beneath the patient was also covered by adsorbent pads. The ${ }^{131} \mathrm{I}$ is administered in capsules delivered to the patient in a shielded container $(3.0 \mathrm{~cm} \mathrm{~Pb})$. Post-administration, the patient is advised to drink several glasses of water in order to clean the mouth of any potential early release of the ${ }^{131}$ I. At this center the practice is that thyroid uptake and imaging are carried out within $24 \mathrm{~h}$ of administration. In Saudi Arabia, the dose limit concerning patient discharge is $18 \mu \mathrm{Sv} / \mathrm{h}$ at a one meter distance with safety and protection instructions. The average hospitalization time is three days upon receiving the ${ }^{131} \mathrm{I}$ capsules, according to the international commission on radiological protection (ICRP), and the international atomic energy agency (IAEA) ${ }^{33,34}$.

Isolation ward. A nuclear medicine department that makes use of ${ }^{131} \mathrm{I}$ as a radioactive source for treatment needs patient waste product to be drained into a separate waste management facility, referred to as a delay tank. There will be a significant amount of radioactive waste generated by the patient. Within three days of administration it has been estimated that almost $70 \%$ of ${ }^{131} \mathrm{I}$ can be excreted in urine from the patient ${ }^{35}$. At KFSH\&RC, patients treated with ${ }^{131}$ I remain in isolation for three days, six isolation rooms being available for this, to protect staff and members of the public from radiation exposure. During the isolation period, waste is drained into isolated delay containers at the department. All parts of the radiation protection policy are carried out in accord with national and international recommendations for occupational and public dose limits. In regard to the maximum annual exposure for staff working with radiation in this particular nuclear medicine department, annual effective dose may be anticipated to be $\geq 2.0 \mathrm{mSv}$ (i.e. $\geq 10 \%$ of the permissible dose limits, applicable to 
the particular medical physicists, physicians, technologists, and nurses). For the purpose of record, the limit is recognized to be $20 \mathrm{mSv} /$ year, $100 \mathrm{mSv}$ for five years, with $50 \mathrm{mSv}$ being the maximum dose for a single year. The annual dose for members of the public (visitors and comforters) is limited to $1.0 \mathrm{mSv}^{36,37}$. In the nuclear medicine department, infants and children are not allowed access to the ward area. At this time, there are no dose limits for the patient for medical procedures.

Staff incorporated radioiodine assessment. Occupational exposure to radioiodine may result in the accumulation of radioiodine in the thyroid. In particular, if staff work in a controlled area then monitoring of the thyroid uptake of staff is recommended, the recorded dose needing to be kept for at least 30 years $^{38}$. The procedure is performed in a sitting position with the detector field of view placed at the neck level. Thyroid activity from incorporated radioiodine was quantified using thyroid uptake measurements for all staff (one medical Physicist and six nursing staff). Thyroid bioassay for staff is used rather than urine samples analysis because it is more accessible, the result is faster, cheap and can be performed on a self-screening basis. Urine analysis is an alternative technique but is require more time and cost for monitoring incorporated radioiodine ${ }^{35}$. Additionally, ambient doses have been measured at the wall, $1.5 \mathrm{~m}$ height. Conversely, for emission from patients during hospitalization, exposure has been estimated based on measurement at 30-, 100-, and $300 \mathrm{~cm}$ using calibrated survey meters (Victoreen 451P, Fluke Biomedical).

The ${ }^{131} \mathrm{I}$ administered activity (AA) was calculated using the following Eq. ${ }^{39}$ :

$$
A(M B q)=\frac{23.4 \times m(g) \times D(G y)}{U \times T}
$$

where 23.4 conversion factor, $\mathrm{m}$ is the thyroid mass in gram, $\mathrm{U}$ the thyroid dose uptake for $24 \mathrm{~h}, \mathrm{D}$ absorbed dose of ${ }^{131} \mathrm{I}$ and $\mathrm{T}$ the effective half-life of radioiodine.

MIRD dose was used for thyroid dose evaluation of the radioiodine activity requisite to accomplish a definite recommended absorbed dose (D) for the thyroid remnant lesion according to Eq. $2^{40}$.

$$
D=\frac{\tilde{A} \times S \times m_{t}}{m_{t}}
$$

where $\tilde{A}$ is cumulative activity, $m_{t}$ is the thyroid mass or remnant lesion in gram (reference mass is $20.7 \mathrm{~g}$ ), $\mathrm{S}$ is dose to thyroid or remnant lesion from unit cumulated radioactivity (S-factor).

Occupational exposure dosimetry and shielding. The current practice mobile shield of the lead equivalent $3 \mathrm{~cm}$ is used for regular practice. Occupational exposure for radioiodine treatment personnel was measured using two groups of thermoluminescent detectors (TLD-100). TLD-100 badge worn on the collar level.Extremity doses were measured using ring dosimeters placed on the dominant hand of the operator. TLD 100 (Harshaw-Bicron, USA) was used in this study, acknowledging their ability to make accurate radiation dose measurements for a wide range of dose from $10^{-7} \mathrm{~Gy}$ to $12 \mathrm{~Gy}^{41}$. Low fading is an essential characteristic of personal dosimetry, enabling dose measurement to be made at two-month intervals in routine departmental work. Calibration of the TLDs was made using a ${ }^{137} \mathrm{Cs}$ source at the Secondary Standard Dosimetry Laboratory (SSDL), also located at the KFSH\&RC. The TLD cards that are used provide for occupational calibration exposure $(\mathrm{mSv})$ in terms of skin dose $(\mathrm{Hp}(0.07))$ and deep dose $(\mathrm{Hp}(10))$. All TLD signals were acquired using a TLD reader (Harshaw 6600) (Harshaw-Bicron Company, USA). The time-temperature profile adopted consisted of $100{ }^{\circ} \mathrm{C}$ preheating and signal acquisition up to $240{ }^{\circ} \mathrm{C}$ at a heating rate of $10{ }^{\circ} \mathrm{C} / \mathrm{s}$. Pre and post-irradiation annealing were applied for all TLDs batch using an automatic Oven (TLDO; Germany), settings being in accord with the manufacturer recommendations.

Ambient dose and patient room measurement. Ambient dose measurements were also performed using calibrated TLD-100 detectors. These were placed at particular key locations around the radioiodine therapy department, including the nursing station (reception) and corridor of the department onto which all of the patients room opened. In addition, dose measurements were also carried out in the patient rooms, at the following locations: toilet, bed and basin, use being made of a survey meter (Victoreen 451P, Fluke Biomedical).

\section{Results}

The results of this study represent a total of 206 patients, 182 (88.3\%) and 24 (11.7\%) receiving iodine therapy for thyroid cancer and hyperthyroidism, respectively. The incidence of thyroid cancer in female is higher compared to the male group. The incidence in female is $10 \%$ and $66 \%$ for hyperthyroidism and thyroid cancer, respectively. Similar findings were reported in previous studies ${ }^{1,3,23,42,43}$. Patient demographic data (age (y), weight $(\mathrm{kg})$ and height $(\mathrm{m})$ ) showed the majority of patients to be overweight and obese, with an average BMI $\left(\mathrm{kg} / \mathrm{m}^{2}\right)$ of $30.1 \pm 5.3$ and of range between 15.4 to 43.4. The mean and range of administered activity (AA, MBq)) for thyroid cancer treatment were $4243.7 \pm 2021.4$ (1668.9-8066.0) (Table 3). The mean and range of AA (MBq) for hyperthyroidism were $1507.9 \pm 324.1$ (977.9-1836.9) (Table 4). The annual occupational doses were $1.2 \mathrm{mSv}$. The ambient doses at the isolation rooms after cleaning, also the corridors, were $0.2 \mathrm{mSv}$. Staff incorporated radioiodine was found to be below the lower limit of detection. Tables 3 and 4 show the dose rate measurements at different distances from the patients over a three days period, with and without a shielding barrier. 


\begin{tabular}{|c|c|c|c|c|c|c|c|c|c|}
\hline \multirow[b]{2}{*}{ Gender } & \multirow[b]{2}{*}{$\begin{array}{l}\text { Administered } \\
\text { activity (MBq) }\end{array}$} & \multicolumn{4}{|c|}{ Dose rate 1st day $(\mu \mathrm{Sv} / \mathrm{h})$} & \multicolumn{2}{|c|}{$\begin{array}{l}\text { Dose rate } 2 \text { nd day } \\
(\mu \mathrm{Sv} / \mathrm{h})\end{array}$} & \multicolumn{2}{|c|}{$\begin{array}{l}\text { Dose rate, 3rd day } \\
(\mu \mathrm{Sv} / \mathrm{h})\end{array}$} \\
\hline & & $30 \mathrm{~cm}$ & $100 \mathrm{~cm}$ & $300 \mathrm{~cm}$ & $\begin{array}{l}\text { Behind bed } \\
\text { shield }\end{array}$ & $30 \mathrm{~cm}$ & $100 \mathrm{~cm}$ & $30 \mathrm{~cm}$ & $100 \mathrm{~cm}$ \\
\hline Male & $\begin{array}{l}4503.0 \pm 2046.6 \\
(1825.5-8066.0)\end{array}$ & $\begin{array}{l}598 \pm 309 \\
(150-1380)\end{array}$ & $\begin{array}{l}114 \pm 56 \\
(25-230)\end{array}$ & $\begin{array}{l}4 \pm 2 \\
(0.1-13)\end{array}$ & $\begin{array}{l}4 \pm 2 \\
(0.1-9)\end{array}$ & $\begin{array}{l}204 \pm 86 \\
(65-380)\end{array}$ & $\begin{array}{l}56 \pm 28 \\
(12-137)\end{array}$ & $\begin{array}{l}77 \pm 46 \\
(0.0-180)\end{array}$ & $\begin{array}{l}(15 \pm 6) \\
(0.0-25)\end{array}$ \\
\hline Female & $\begin{array}{l}3984.3 \pm 1996.2 \\
(1512.2-8066.0)\end{array}$ & $\begin{array}{l}499 \pm 311 \\
(100-1370)\end{array}$ & $\begin{array}{l}(99 \pm 53) \\
(25-240)\end{array}$ & $\begin{array}{l}4 \pm 2 \\
(0.1-12)\end{array}$ & $\begin{array}{l}4 \pm 2 \\
(0.3-12)\end{array}$ & $\begin{array}{l}165 \pm 82 \\
(35-640)\end{array}$ & $\begin{array}{l}41 \pm 23 \\
(11-150)\end{array}$ & $\begin{array}{l}51 \pm 33 \\
(6-150)\end{array}$ & $\begin{array}{l}11 \pm 5 \\
(1-30)\end{array}$ \\
\hline Total & $\begin{array}{l}4243.7 \pm 2021.4 \\
(1512.2-8066.0)\end{array}$ & $\begin{array}{l}5490 \pm 3150 \\
(1250-1380)\end{array}$ & $\begin{array}{l}(107 \pm 5.5) \\
(25-240)\end{array}$ & $\begin{array}{l}40 \pm 20 \\
(0.1-13)\end{array}$ & $\begin{array}{l}4 \pm 2 \\
(0.1-12)\end{array}$ & $\begin{array}{l}185 \pm 84 \\
(50-640)\end{array}$ & $\begin{array}{l}49 \pm 26 \\
(11-150)\end{array}$ & $\begin{array}{l}64 \pm 39 \\
(0-180)\end{array}$ & $\begin{array}{l}13 \pm 5.5 \\
(0.0-30)\end{array}$ \\
\hline
\end{tabular}

Table 3. Mean, \pm Sd and range of patient demographic data in thyroid cancer by using Iodine- 131 .

\begin{tabular}{|c|c|c|c|c|c|c|c|c|c|}
\hline \multirow[b]{2}{*}{ Gender } & \multirow[b]{2}{*}{$\begin{array}{l}\text { Administered } \\
\text { activity (MBq) }\end{array}$} & \multicolumn{4}{|c|}{ Dose rate first day $(\mu \mathrm{Sv} / \mathrm{h})$} & \multicolumn{2}{|c|}{$\begin{array}{l}\text { Dose rate second day } \\
(\mu \mathrm{Sv} / \mathrm{h})\end{array}$} & \multicolumn{2}{|c|}{$\begin{array}{l}\text { dose rate discharge } \\
\text { day }(\mu \mathrm{S} v / \mathrm{h})\end{array}$} \\
\hline & & $30 \mathrm{~cm}$ & $100 \mathrm{~cm}$ & $300 \mathrm{~cm}$ & $\begin{array}{l}\text { Behind bed } \\
\text { shield }\end{array}$ & $30 \mathrm{~cm}$ & $100 \mathrm{~cm}$ & $30 \mathrm{~cm}$ & $100 \mathrm{~cm}$ \\
\hline Male & $\begin{array}{l}1187.21 \pm 33.1 \\
(1149.2-1209.9)\end{array}$ & $\begin{array}{l}154 \pm 41.2 \\
(120-200)\end{array}$ & $\begin{array}{l}29 \pm 12 \\
(17.6-41)\end{array}$ & $\begin{array}{l}1.9 \\
(1.0-3.0)\end{array}$ & $\begin{array}{l}2.3 \\
(1.0-5.0)\end{array}$ & $\begin{array}{l}89 \pm 26 \\
(65-117)\end{array}$ & $\begin{array}{l}18 \pm 5 \\
(15-24)\end{array}$ & $\begin{array}{l}38 \pm 12 \\
(24-46)\end{array}$ & $\begin{array}{l}(9 \pm 4) \\
(5-12)\end{array}$ \\
\hline Female & \begin{tabular}{|l|}
$1190.9 \pm 120.9$ \\
$(806.6-1313.5)$ \\
\end{tabular} & $\begin{array}{l}147 \pm 44 \\
(65-240)\end{array}$ & $\begin{array}{l}31 \pm 8 \\
(17-45)\end{array}$ & $\begin{array}{l}2.6 \\
(1.0-9.0) \\
\end{array}$ & $\begin{array}{l}2.1 \\
(1.0-7.0)\end{array}$ & $\begin{array}{l}56 \pm 23 \\
(0.0-100)\end{array}$ & $\begin{array}{l}13 \pm 5 \\
(0.0-22)\end{array}$ & $\begin{array}{l}22 \\
(0.0-70)\end{array}$ & $\begin{array}{l}5.8 \pm 4.8 \\
(0.0-15)\end{array}$ \\
\hline Overall & \begin{tabular}{|l|}
$1189.1 \pm 77.0$ \\
$(806.6-1313.5)$
\end{tabular} & $\begin{array}{l}1510 \pm 430 \\
(65-240)\end{array}$ & $\begin{array}{l}30 \pm 10 \\
(17-45)\end{array}$ & \begin{tabular}{|l}
2.3 \\
$(1.0-9.0)$
\end{tabular} & $\begin{array}{l}2.2 \\
(1.0-7.0)\end{array}$ & $\begin{array}{l}73 \pm 25 \\
(0-117)\end{array}$ & $\begin{array}{l}16 \pm 5 \\
(0.0-24)\end{array}$ & $\begin{array}{l}(27 \pm 17) \\
(0-70)\end{array}$ & $\begin{array}{l}7.4 \pm 4.4 \\
(0.0-15)\end{array}$ \\
\hline
\end{tabular}

Table 4. Mean, $\pm \mathrm{Sd}$ and range of patient demographic data for Hyperthyroidism by using Iodine- 131 .

\section{Discussion}

For particular thyroid disorders, Iodine-131 therapy represents a highly effective theranostic radiopharmaceutical, with an ability to provide safe treatment as a result of the significant beta-decay component. Conversely, for nuclear medicine personnel, gamma emission represents the primary source of external exposure. Administration is made of significant radioactivity, typically with radioiodine treatment activities ranging from some 1700 - to in-excess of $8000 \mathrm{MBq}$ per patient. With this, patients effectively become an open-source of radiation exposure to surrounding personnel and to the environment, the latter through body fluids excretion. Patient dose is monitored daily to ensure dose reduction accords with treatment planning. In respect of hospital protocol, seeking to ensure that family members are well protected, patients are typically released when the doserate falls to below $18 \mu \mathrm{Sv} / \mathrm{h}$ at a distance of one metre. The practice varied considerably regarding the release of patients from the hospital after radioiodine therapy. For example, in Japan, $500 \mathrm{MBq}$ or $<30 \mu \mathrm{Sv} / \mathrm{h}$ at $1 \mathrm{~m}$ distance while for Germany it is $250 \mathrm{MBq}$ or $<3.5 \mu \mathrm{Sv} / \mathrm{h}$ at $1 \mathrm{~m}$ distance, and in the USA it is $1200 \mathrm{MBq}$ or $<70$ $\mu \mathrm{Sv} / \mathrm{hr}$ at $1 \mathrm{~m}$ distance. The IAEA and ICRP recommended that the release of patients treated with radioiodine should be decided on an individual basis ${ }^{33,34}$. Although in present study staff thyroid doses were found to be below the detection limit, others have reported that measured activities have ranged from $5.0 \pm 2 \mathrm{~Bq}$ to $217 \pm 56$ $\mathrm{Bq}^{44},{ }^{25,45}$. The average occupational dose and range (in $\mathrm{mSv}$ ) from this study were found to be $1.2(1.0-1.3) \mathrm{mSv}$ per year, while the ambient dose was found to be $0.2 \mathrm{mSv}$ per year, occupational doses being higher than most values reported in the literature (Figure 2). Previously reported that occupational exposure is patient mobility dependent. Self-caring patients expose the staff to lower doses compared to dependent patients ${ }^{45}$. Of note is that this occupational exposure includes only radiation doses resulting from the working environment. All other sources of other exposure have been excluded, including background radiation and medical exposure as a patient. In present study, the radiation-induced cancer risk from occupational exposure has been found to be well below the annual exposure limit of $20 \mathrm{mSv} /$ year. Figure 2 showed the annual occupational exposure in previous studies $23,25,46-48$. The wide variation of occupational exposure attributed to the variation in the radioisotopes used in the department, radiation protection measures and the type of activity conducted by nuclear medicine personnel. Physicians received the least doses while technologist and nurses received the highest doses. Particular guidelines, including in regard to time, distance and shielding will help to ensure that the annual dose is kept well below the limit ${ }^{26}$.

\section{Conclusions}

In the light of current practice, albeit applied to a relatively high workload, staff exposures were found to be below $1.2 \mathrm{mSv}$, the annual dose limits being $20.0 \mathrm{mSv}$. Occupational doses have been found higher than most of previously published studies. Proper patient isolation is an essential factor in staff radiation dose reduction. 


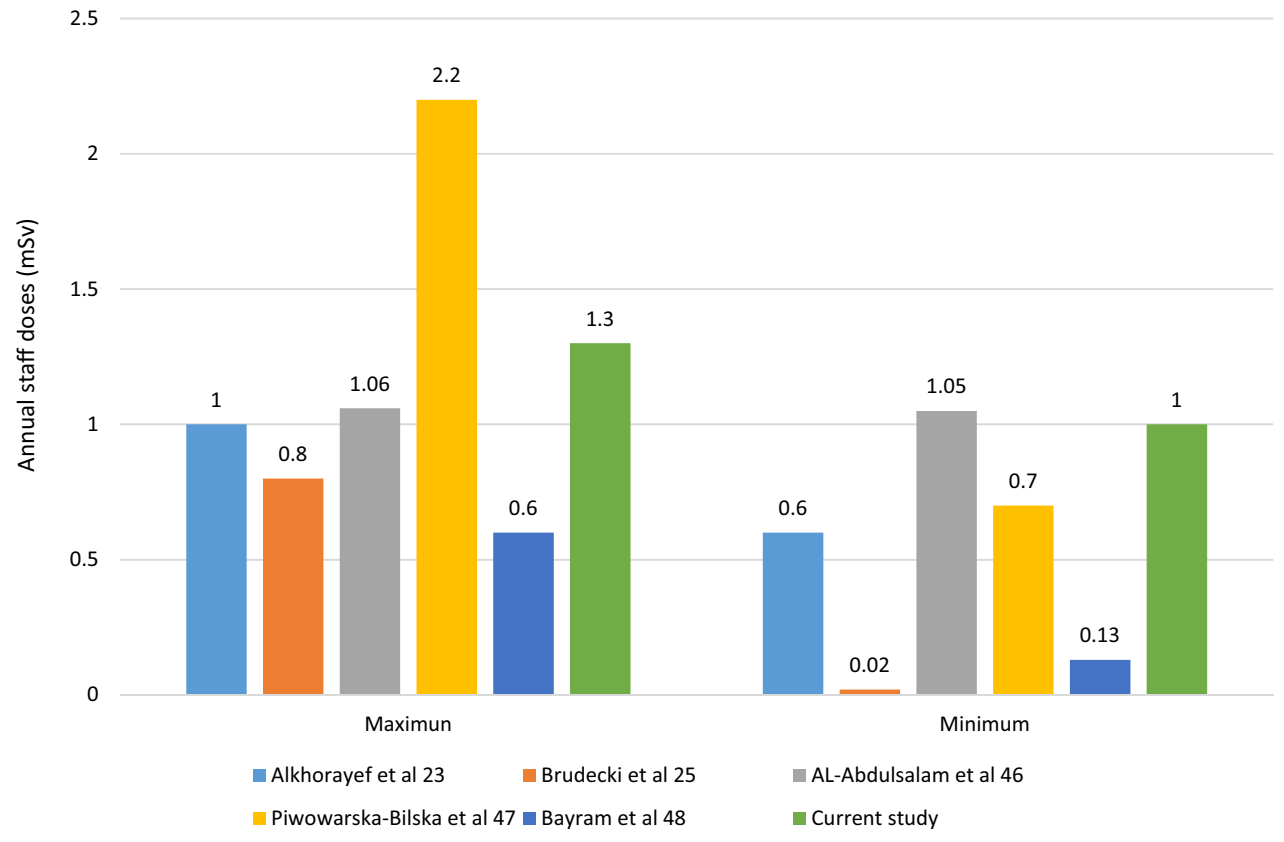

Figure 2. Occupational exposures compared to that recorded in previous studies.

Current practice is noted to comply with international guidelines, the adoption of radiation safety recommendations being found highly effective in control of staff and public exposures.

Received: 8 March 2021; Accepted: 17 June 2021

Published online: 15 July 2021

\section{References}

1. SCR. Kingdom of Saudi Arabia Saudi Health Council National Health Information Center Saudi Cancer Registry. Cancer Incidence Report Saudi Arabia 2015 (2018). https://nhic.gov.sa/eServices/Documents/E\%20SCR\%20final\%206\%20NOV.pdf.accessed Nov $12,2020$.

2. Sung, H. et al. Global cancer statistics 2020: GLOBOCAN estimates of incidence and mortality worldwide for 36 cancers in 185 countries. CA Cancer J. Clin. https://doi.org/10.3322/caac.21660 (2021).

3. Hussain, F. et al. Incidence of thyroid cancer in the Kingdom of Saudi Arabia, 2000-2010. Hematol. Oncol. Stem Cell Ther. 6, 58-64 (2013).

4. Haugen, B. R. et al. 2015 American Thyroid Association Management guidelines for adult patients with thyroid nodules and differentiated thyroid cancer: the American Thyroid Association guidelines task force on thyroid nodules and differentiated thyroid cancer. Thyroid 26, 1-133 (2016).

5. Korkusuz, H., Happel, C., Koch, D. A. \& Gruenwald, F. Combination of ultrasound-guided percutaneous microwave ablation and radioiodine therapy in benign thyroid disease: a 3-month follow-up study. Rofo. 188(1), 60-68 (2016).

6. Happel, C., Korkusuz, H., Koch, D. A., Grünwald, F. \& Kranert, W. T. Combination of ultrasound guided percutaneous microwave ablation and radioiodine therapy in benign thyroid diseases. A suitable method to reduce the 131I activity and hospitalization time?. Nuklearmedizin 54(3), 118-124 (2015).

7. Happel, C., Korkusuz, H., Kranert, W. T. \& Grünwald, F. Combination of ultrasound guided percutaneous microwave ablation and radioiodine therapy for treatment of hyper- and hypofunctioning thyroid nodules. Nuklearmedizin 53(6), N48-N49 (2014).

8. Min, Y. et al. Thermal ablation for papillary thyroid microcarcinoma: how far we have come?. Cancer Manag. Res. 12, 13369-13379 (2020).

9. Yue, W. W. et al. US-guided microwave ablation of low-risk papillary thyroid microcarcinoma: longer-term results of a prospective study. J. Clin. Endocrinol. Metab. 105(6), 128 (2020).

10. Trimboli, P., Pelloni, F., Bini, F., Marinozzi, F. \& Giovanella, L. High-intensity focused ultrasound (HIFU) for benign thyroid nodules: 2-year follow-up results. Endocrine 65(2), 312-317 (2019).

11. Zhou, W. et al. Ultrasound-guided laser ablation versus microwave ablation for patients with unifocal papillary thyroid microcarcinoma: a retrospective study. Lasers Surg. Med. 52, 855-862 (2020).

12. Zhang, M. et al. Ultrasound-guided radiofrequency ablation versus surgery for low-risk papillary thyroid microcarcinoma: results of over 5 years' follow-up. Thyroid 30(3), 408-417 (2020).

13. Biamonte, E. et al. Medullary thyroid carcinoma treated with percutaneous ultrasound-guided radiofrequency ablation. Endocrine 65(3), 515-519 (2019).

14. Deng-Ke, T. et al. Preliminary report of microwave ablation for the primary papillary thyroid microcarcinoma: a large-cohort of 185 patients feasibility study. Endocrine 64(1), 109-117 (2019).

15. Izadifar, Z., Izadifar, Z., Chapman, D. \& Babyn, P. An introduction to high intensity focused ultrasound: systematic review on principles, devices, and clinical applications. J Clin Med. 9(2), 4601-4622 (2020).

16. Trimboli, P. et al. Efficacy of thermal ablation in benign non-functioning solid thyroid nodule: a systematic review and metaanalysis. Endocrine 67(1), 35-43 (2020).

17. Pacella, C. \& Papini, E. Thermal ablation procedures: the need of careful appraisal. Endocrine 67(1), 268-269 (2020).

18. Hong, C. M. \& Ahn, B.-C. Redifferentiation of radioiodine refractory differentiated thyroid cancer for reapplication of I-131 therapy. Front Endocrinol. 8, 260 (2017). 
19. Bozkurt, M. F. \& Özcan, Z. The evolving role of nuclear medicine and molecular imaging: theranostics and personalized therapeutic applications. Mol. Imaging Radionucl. Ther. 27, 1-2 (2018).

20. Piccardo, A., Trimboli, P., Bottoni, G. \& Giovanella, L. Radioiodine ablation of remaining thyroid lobe in patients with differentiated thyroid cancer treated by lobectomy: a systematic review and metaanalysis. J. Nucl. Med. 61(12), 1730-1735 (2020).

21. Wang, X., Zhu, J., Li, Z. \& Wei, T. The benefits of radioactive iodine ablation for patients with intermediate-risk papillary thyroid cancer. PLoS ONE 15(6), e0234843 (2020).

22. ICRP Publication 140. Radiological protection in therapy with radiopharmaceuticals. Ann. ICRP 48(1), 5-95 (2019).

23. Alkhorayef, M. et al. Staff and ambient radiation dose resulting from therapeutic nuclear medicine procedures. Appl. Radiat. Isot. 141, 270-274 (2018)

24. Bitar, A., Maghrabi, M. \& Doubal, A. W. Assessment of intake and internal dose from ${ }^{131} \mathrm{I}$ for exposed workers handling radiopharmaceutical products. Appl. Rad. Isot. 82, 370-375 (2013).

25. Brudecki, K., Szczodry, A., Mróz, T., Kowalska, A. \& Mietelski, J. W. Measurement of 131I activity in air indoor Polish nuclear medical hospital as a tool for an internal dose assessment. Radiat. Environ. Biophys. 57, 77-82 (2018).

26. Abu-Khaled, Y. S., Sandouqa, A. S. \& Haddadin, I. M. Radiation exposure from radioactive iodine 131 in and surrounding the patients' room. Radiat Prot. Dosim 135, 64-68 (2009).

27. Dobrzynska, M., Pachocki, K., Gajowik, A., Radzikowska, J. \& Sackiewicz, A. The effect occupational exposure to ionizing radiation on the DNA damage in peripheral blood leukocytes of nuclear medicine personnel. J. Occip. Health. 56(5), 379-386 (2014).

28. Ramos, V. S., Crispim, V. R. \& Brandão, L. E. B. New filter for iodine applied in nuclear medicine services. Appl. Radiat. Isot. 82, $111-118(2013)$.

29. IAEA, 1999. International Atomic Energy Agency. Assessment of occupational exposure due to intakes of radionuclides. Safety Standards Series No. RS-G-1.2.

30. Thrall, J.H., Ziessman, H.A. Nuclear Medicine-The Requisites Mosby Year Book, St. Louis Missouri (1995).

31. Miszczyk, J. et al. Assessment of the nuclear medicine personnel occupational exposure to radioiodine. Eur. J. Radiol. 121, 1-7 (2019).

32. Krajewska, G. \& Pachocki, K. A. Assessment of exposure of workers to ionizing radiation from radioiodine and technetium in nuclear medicine departmental facilities. Med. Pr. 64(5), 625-630 (2013).

33. ICRP, 2004. Release of Patients after Therapy with Unsealed Radionuclides. ICRP Publication 94. Ann. ICRP 34 (2).

34. International atomic energy agency (IAEA). Release of patients after radionuclide therapy. Safety reports series No. 63. IAEA, Vienna, 2009

35. Happel, C., Bockisch, B., Kratzel, U., Grünwald, F. \& Kranert, W. T. Five years of incorporation monitoring on an 131I therapy ward-is incorporation monitoring required for routine?. Rep. Thyroid Res. 1(1), 1011-1017 (2017).

36. Leung, P. M. \& Nikolic, M. Disposal of therapeutic 131I waste using a multiple holding tank system. Health. Phys. 75(3), 315-321 (1998).

37. ICRP. 1990 Recommendations of the international commission on radiological protection. ICRP Publication 60. Ann. ICRP 21(1-3), 1-211 (1991).

38. IAEA, 2014. International Atomic Energy Agency. Radiation protection and safety of radiation sources: international basic safety standards. IAEA Safety standards series No. GSR Part 3.

39. Marinelli, L. D., Quimby, E. H. \& Hine, G. J. Dosage determination with radioactive isotopes; practical considerations in therapy and protection. Am. J. Roentgenol. Radium Ther. 59, 260-281 (1948).

40. Stabin, M. G. Dosimetric and radiobiologic considerations. In Nuclear Medicine in Clinical Diagnosis and Treatment 3rd edn (eds Ell, P. J. \& Gambhir, S. S.) 363-373 (Churchill Livingstone, 2004).

41. Al-Mohammed, H. I., Mahyoub, F. H. \& Moftah, B. A. Comparative study on skin dose measurement using MOSFET and TLD for pediatric patients with acute lymphatic leukemia. Med. Sci. Monit. 16(7), CR325-CR329 (2010).

42. Kochovska, M. Z., Jokic, V. S., Majstorov, V. \& Dugonjic, S. Estimated dose to family members of patients treated with radioiodine. Radiat. Prot. Dosim. 174(2), 250-254 (2017).

43. Al-Haj, A. N., Lagarde, C. S. \& Lobriguito, A. M. Patient parameters and other radiation safety issues in 131I therapy for thyroid cancer treatment. Health Phys. 93(6), 656-666 (2007).

44. Adliene, D., Griciene, B., Skovorodko, K., Laurikaitiene, J. \& Puiso, J. Occupational radiation exposure of health professionals and cancer risk assessment for Lithuanian nuclear medicine workers. Environ. Res. 183(109144), 1-10 (2020).

45. Barrington, S. F. et al. Radiation dose rates from patients receiving iodine-131 therapy for carcinoma of the thyroid. Eur. J. Nucl. Med. 23, 123-130 (1996).

46. Al-Abdulsalam, A. \& Brindhaban, A. Occupational radiation exposure among the staff of Departments of Nuclear Medicine and Diagnostic Radiology in Kuwait. Med. Princ. Pract. 23, 129-133 (2014).

47. Piwowarska-Bilska, H. et al. Occupational exposure at the Department of Nuclear Medicine as a work environment: a 19-year follow-up. Pol. J. Radiol. 76(2), 18-21 (2011).

48. Bayram, T., Yilmaz, A., Demir, M. \& Sonmez, B. Radiation dose to technologists per nuclear medicine examination and estimation of annual dose. J. Nucl. Med. Technol. 39, 55-59 (2011).

\section{Author contributions}

H.A. and A.S., F.M., M.A., H.S., A.A., A.D., D.B. designed experiments; conducted experiments; collected and analyzed data; wrote and edited paper. H.A. M.A.C.K., C.L., D.B. \& A.S. contributed to analysis, writing, editing and funding of the work. All authors reviewed the manuscript and approved it.

\section{Funding}

The authors extend their appreciation to the International Scientific Partnership Program ISPP at King Saud University for funding this research work through ISPP 150.

\section{Competing interests}

The authors declare no competing interests.

\section{Additional information}

Correspondence and requests for materials should be addressed to A.S.

Reprints and permissions information is available at www.nature.com/reprints.

Publisher's note Springer Nature remains neutral with regard to jurisdictional claims in published maps and institutional affiliations. 
(c) (i) Open Access This article is licensed under a Creative Commons Attribution 4.0 International cc) License, which permits use, sharing, adaptation, distribution and reproduction in any medium or format, as long as you give appropriate credit to the original author(s) and the source, provide a link to the Creative Commons licence, and indicate if changes were made. The images or other third party material in this article are included in the article's Creative Commons licence, unless indicated otherwise in a credit line to the material. If material is not included in the article's Creative Commons licence and your intended use is not permitted by statutory regulation or exceeds the permitted use, you will need to obtain permission directly from the copyright holder. To view a copy of this licence, visit http://creativecommons.org/licenses/by/4.0/.

(C) The Author(s) 2021 